\title{
CLOSING THE LOOP: THE CHALLENGES OF REGULATION IN MUNICIPAL SOLID WASTE MANAGEMENT
}

\author{
Shira Daskal ${ }^{1, \star}$, Ofira Ayalon ${ }^{1,2}$ and Mordechai Shechter ${ }^{1}$ \\ ${ }^{1}$ University of Haifa - The Department of Natural Resources and Environmental Management, 199 Aba Khoushy Avenue, \\ Mount Carmel, Haifa, Haifa 3498838, Israel \\ ${ }^{2}$ Samuel Neaman Inst., Haifa, Israel
}

Article Info:
Received:
28 June 2018
Revised:
18 November 2018
Accepted:
10 December 2018
Available online:
8 March 2019
Keywords:
Regulatory Impact Assessment
Legislation
Management
Regulation
SWOT
Arena
Israel

\section{INTRODUCTION}

Regulation has a profound impact on markets and in recent decades it has also been perceived as a solution to a wide range of environmental problems. Environmental regulation is mainly based on the implementation of various regulatory principles and tools (such as command and control, green taxation and extended producer responsibility) to advance environmental and natural resources management (Sterner \& Coria, 2012). Ensuring the right regulatory framework is essential for the development of the circular economy in the single market (EC, 2016). However, regulation may also induce barriers and undesirable effects, thus the regulatory tools selected by the regulator are critical to achieving the desired goals and objectives (Marques \& Simões, 2008). In recent years, there has been a rise in awareness for the need to monitor, evaluate and supervise regulation itself, its effectiveness and its associated processes (OECD, 2002; OECD, 2009).

Regulatory Impact Analysis and Assessment (RIA) is a systemic approach to critically assessing the positive and negative effects of proposed and existing regulations and non-regulatory alternatives, intended to be implemented as a tool for the measurement and evaluation of social, economic and environmental regulatory effects to assist policymakers in the design, implementation, monitoring and improvement of regulatory policies and systems (Kirkpatrick \& Parker, 2007; Kirkpatrick et al. 2004; OECD, 2009). This key tool is universally used in OECD and EU countries to improve efficiency, transparency and, accountability for regulatory decision-making (Adelle et al., 2014) and is formulated from systematic advice and clear policy criteria based, including economic analysis and the impact of cost efficiency and cost effectiveness, taking into consideration various factors and stakeholders (Arndt et al., 2015; OECD, 2002). RIA is also cited as a factor leading to a more democratic regulation, particularly in complex political systems (Radaelli \& Francesco, 2007).

A full RIA should include cost \& benefit analysis and/ or cost-effectiveness analysis, defining the various alterna- 
tives in place and time frameworks, along with the components of uncertainty and risks (Garber \& Phelps, 1997; Johannesson, 1995; OECD, 2006; OEDC, 2011; OECD, 2015; Schneider et al, 2012; Zurbrugg et al, 2014). There has been a significant increase in RIA adoption in all areas of regulation in the jurisdictions of the OECD countries since the mid-1970s, reaching over 34 jurisdictions in 2014 (OECD, 2015).

One of the significant environmental challenges characterized by extensive regulation is Municipal Solid Waste (MSW) management. The responsibility for the storage, collection, and disposal of MSW is in most cases of the local authorities, whilst the regulation constitutes a key tool for implementing strategies and plans to enhance the ability to handle the growing amount of the end-oflife components of consumption products (Ayalon et al., 1999; Broitman et al., 2012; Kinnaman, 2014; Marques \& Simões, 2008; Pan et al., 2015; Simões \& Marques, 2012b).

Even though it is a controversial method and considered to be an unsustainable one, landfilling is still the most common way in the world to dispose MSW and is relevant even when other advanced options are being used for recycling and/or volume reduction (Agamuthu, 2013; Ayalon et al, 2000, Broitman et al 2012). In Israel, the population reached 8.69 million in 2017 with an average gross domestic product (GDP) of 35,817 Euros/per capita, for 2016 (Central Bureau of Statistics, 2017; Di Maria et al., 2017), the local authorities are responsible for the storage, collection, and disposal of MSW, while the Israeli Ministry of Environmental Protection (IMoEP) is responsible for the formulation and implementation of waste management policies and legislation (IMoEP, 2018). Various services for the storage, collection, and disposal of MSW in Israel are provided by the private sector based on public tenders published by the local authorities. However, the private sector does not take part in the management of those arrangements. A retrospective analysis of the regulation in Israel between the years 2005 till 2015 shows that during this period about $80 \%$ of the MSW in Israel has been landfilled and recycling rates have not increased, despite regulations (Daskal et al., 2018). The case of Israel shows that even when there is an extensive regulation that includes a wide range of laws, economic penalties and financial incentives (such as landfill levy and financing of MSW separation at source arrangements), this does not guarantee proper treatment or even an improvement in MSW management. In the case of Israel, the lack of suitable infrastructure for MSW treatment has paralyzed this market, which has resulted in no change in the rate of landfilling for over 12 years.

This paper presents the analysis of the MSW market in Israel in light of IMoEP's strategic goal of landfilling reduction by increasing recycling and the regulation and legislation designed and implemented for achieving this goal. The MSW market relates to the nominal and actual place in which goods and services related to the storage, collection, and disposal of MSW are traded and handled. The analysis of the MSW market included building the Arena of the MSW market by mapping the main actors by sectors and identifying the interrelationship and conflicts between the different stakeholders in the market. Strengths, Weaknesses, Opportunities, and Threats (SWOT) analysis was performed based on a survey of 40 experts in the field of MSW, and the results were elaborated to identify the core strategic competencies and root problems for achieving the regulator's goal of reducing landfilling. The core strategic capabilities were identified using the Core Competence Tree (CCT) methodology, by tying logical connections between the desirable phenomena and the root problems were identified using the Focused Current Reality Tree (fCRT) methodology, by tying logical connections between the undesirable phenomena (Coman \& Ronen, 2002; Coman \& Ronen, 2009; Ronen \& Pass, 2008).

Following this introduction, this article is structured as follows: Section 2 presents the methodologies used for the analysis of the MSW market in Israel. Section 3 presents the results and discussion and Section 4 concludes the paper.

\subsection{List of Acronyms}

$\begin{array}{ll}\text { CCT } & \text { Core Competence Tree } \\ \text { EU } & \text { European Union } \\ \text { F.A.S.T. } & \text { Focused Arena Strategy } \\ \text { fCRT } & \text { Focused Current Reality Tree } \\ \text { FM } & \text { Focused Management } \\ \text { GDP } & \text { Gross Domestic Product } \\ \text { IMoEP } & \text { Israeli Ministry of Environmental Protection } \\ \text { MSW } & \text { Municipal Solid Waste } \\ \text { OECD } & \text { Organisation for Economic Co-operation and De- } \\ & \text { velopment } \\ \text { RIA } & \text { Regulatory Impact Analysis and Assessment } \\ \text { SWOT } & \text { Strengths- Weaknesses- Opportunities -Threats } \\ \text { TOC } & \text { Theory of Constraints } \\ \text { VFM } & \text { Value Focused Management }\end{array}$

\section{METHODOLOGIES}

\subsection{The market analysis in the frame of regulatory impact assessment}

RIA can be performed to evaluate regulation already implemented to indicate whether its targets and goals were achieved and whether gaps exist, efficiently identifying them (retrospective analysis). RIA can be performed for evaluating future regulation; this requires a pre-defined set of alternatives and methodological tools for comparing between them (forecast analysis). In both cases-retrospective analysis and forecast analysis-RIA must include market analysis as a baseline. The market analysis is the basic part and the basis of the full RIA model that was developed for RIA implementation of the MSW market in Israel. Results of the retrospective analysis were presented by Daskal et al. (2018).

Figure 1 shows a schematic diagram of the market analysis within the frame of the full RIA model.

There are various approaches and methods for analyzing performance based on cost and efficiency of the waste sector, taking into consideration various factors that affect the cost (Simões \& Marques, 2012a; Simões \& Marques, 2012b). Tools for analysis and evaluation of economic efficiency and operational efficiency are at the 


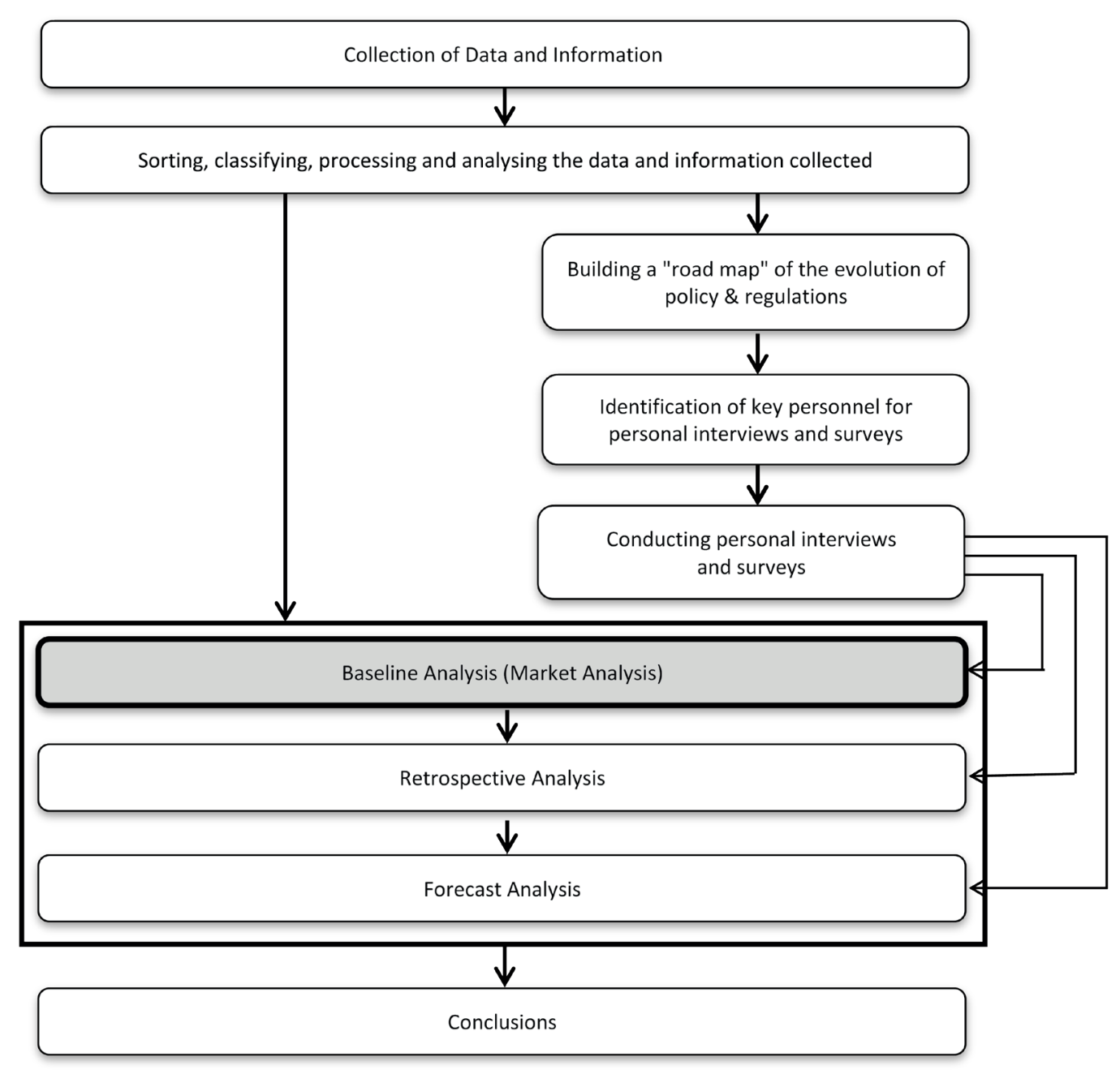

FIGURE 1: Schematic diagram - market analysis within the full RIA model flow.

core of the business administration discipline and therefore these models were adopted to perform RIA and assess the efficiency and effectiveness of the regulation in Israel. The models listed below are based on innovative approaches to improving value and performance: Focused Management (Ronen \& Pass, 2008); Theory of Constraints (Goldratt \& Cox, 2016); Focused Arena (Coman, 2008; Coman \& Ronen, 2009); Value Focused Management (Ronen \& Pass, 2008). An additional tool for strategic analysis is the Strengths, Weaknesses, Opportunities, and Threats (SWOT) model. SWOT is an efficient and easy-to-use analysis tool which results can be visually displayed and communicated (Graczyk \& Rybaczewska, 2007; Pesonen \& Horn, 2013; Ronen \& Pass, 2008; Srivastava et al., 2005; Yuan, 2013). Mor et al. (2015) conducted a SWOT analysis of MSW treatment practices in Chandigarh, India, and found that this approach helps in developing strategic action plans for the development of sustainable cities, effectively integrating the community, the private sector, and local authorities.

The MSW market analysis in Israel was conducted based on a model that integrated various approaches and models including Focused Management (FM), Focused Arena Strategy (F.A.S.T), Theory of Constraints (TOC) and
Value Focused Management (VFM) that were originally conducted in business management and industrial engineering disciplines (Coman \& Ronen, 2002; Goldratt \& Cox, 2016; Ronen, 2005; Ronen \& Pass, 2008).

In the following sections 2.2-2.5, the methodologies of the market analysis are presented- Arena, SWOT, CCT, and fCRT.

\subsection{The MSW market Arena}

The Arena model is a strategic tool for the analysis of a market or an industry; it includes the location of different organizations in the environment in which they operate and their interrelationship (Coman, 2008; Coman \& Ronen, 2002; Ronen \& Pass, 2008). The methodology presented in this paper focuses on two main stages of the analysis and construction of the market Arena: (1) Mapping the main actors in the MSW market by sectors as detailed in section 2.2.1. (2) Analyzing the interrelationship and conflicts between different stakeholders in the market as detailed in section 2.2.2.

\subsubsection{Mapping the main actors in the MSW market by sec-} tors

The first stage of building the MSW market's Arena 
dealt with mapping the main actors in the market according to sectors. In order to identify the main actors including key persons in the MSW market in Israel, an extensive survey was conducted. The survey included collecting data and documents including laws, minutes of government meetings, local government tenders, contracts of local authorities with various contractors, local authorities' financial reports and more.

\subsubsection{The interrelationship and conflicts between different stakeholders in the market}

The second stage of building the MSW market's Arena focused on identifying interrelations and conflicts between actors of various sectors. A significant conflict is a phenomenon known as "Not in My Back Yard" (NIMBY). This phenomenon is characterized by objections to the location of undesirable facilities such as renewable energy facilities (Horst, 2007) and the establishment of sites and facilities for the treatment of MSW (Garrar, 1993). A significant aspect of land use that's considered to be hazardous is distributive justice (Rosen-Zvi, 2007; Nakazawa, 2015) thus residents not only object to the exposure to various environmental hazards but also to inconveniences and a decline in the value of their real estate property (Eshet et al., 2007).

The conflict with residents reflects a conflict of interest in achieving the same goal, as the residents are also interested in an alternative solution to landfilling that will reduce the negative externalities and will enable conservation of land, factors that in bottom line result in a higher standard of living.

The literature shows that it is possible to reduce residents' objections by various means such as legal proceedings, persuasion, compensation (money), public campaigns, education and information, legislation and political proceedings, as well as by mobilizing people in a public status to support an idea or a plan (Halstead et al, 1993; Lee \& Jones, 1991; Nissim et al, 2005). Additionally, some case studies from other places in the world present concrete solutions (Halstead et al, 1993; Lee \& Jones, 1991; Rahardyana et al, 2004), these case studies indicate that this conflict may also be solvable in other places in the world, as well as in Israel.

\subsection{Strengths, Weaknesses, Opportunities, Threats}

The Strengths, Weaknesses, Opportunities, and Threats (SWOT) analysis originates in the business administration discipline but is also widely used in other disciplines and is a cornerstone of strategic analysis to identify and analyze strengths, weaknesses, opportunities and threats in an organization's internal and external environment (Coman \& Ronen, 2009; Rachid \& Fadel, 2013, Ronen \& Pass, 2008; Yuan, 2013). This methodology is also used to analyze and evaluate projects and as a basis for strategic decision-making (Coman \& Ronen, 2009; Rachid \& Fadel, 2013; Ronen and Pass, 2008; Yuan, 2013).

The methodology for performing the SWOT analysis in the current research consisted of a survey of experts that included 40 key persons that were identified as part of the construction of the market's Arena. The survey of experts resulted in the mapping of various phenomena in the MSW market according to the four SWOT categories as shown in Table 1 in section 3.2.

\subsection{Core Competence Tree}

The Core Competence Tree (CCT) is a methodology that enables the identification of core competencies for achieving desired goals and objectives.

The method: take the desirable phenomena from SWOT, i.e. strength and opportunities, and form the CCT by tying logical connections between the desirable phenomena. The desirable phenomenon always leads to achieving the defined goal, revealing 1 to 4 strategic root core competences which are the core strategic capabilities to be strengthened and to which the activity must be strategically subordinated (Coman \& Ronen, 2002; Coman \& Ronen, 2009; Ronen \& Pass, 2008).

The CCT of Israeli MSW market is shown in Figure 3 in section 3.3.

\subsection{Focused Current Reality Tree}

The Focused Current Reality Tree (fCRT) is a methodology that enables the identification of root problems that prevent achieving desired goals and objectives.

The method: take the undesirable phenomena from SWOT, i.e. weaknesses and threats, and form the fCRT by tying logical connections between the undesirable phenomena as it leads to "the goal is not achieved", revealing 1 to 4 strategic root problems that prevent the achievement of the goal (Coman \& Ronen, 2002; Coman \& Ronen, 2009; Ronen \& Pas, 2008).

The fCRT of Israeli MSW market is shown in Figure 4 in section 3.4 .

\section{RESULTS AND DISCUSSION}

\subsection{Arena of the MSW market in Israel}

The survey conducted to map main actors in the MSW market in Israel resulted in identifying the following sectors:

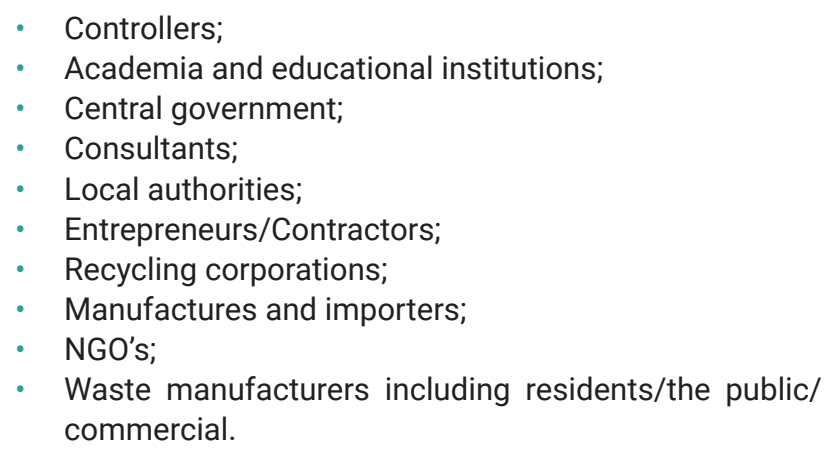

A significant conflict that emerged from the experts' survey is the NIMBY conflict between residents and the local authorities, who have responsibility for managing and handling MSW. Figure 2 shows a diagram illustrating the analysis of the Not in My Back Yard (NIMBY) conflict at the case of the local authorities. In this case, both parties share the identical goal of the reduction of MSW landfilling, however, the residents object to the establishment of infrastructure for the treatment of waste. This conflict can 


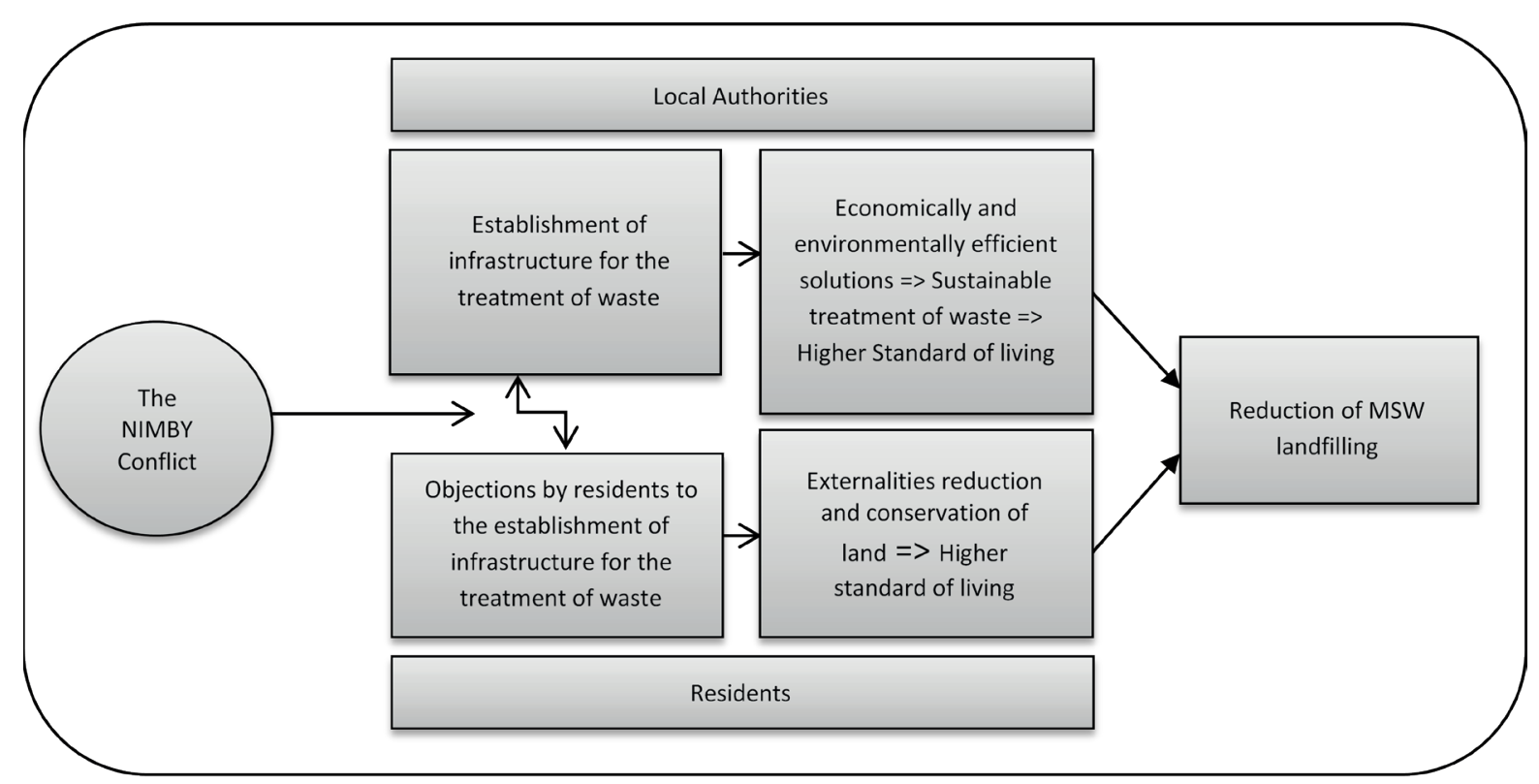

FIGURE 2: A diagram illustrating the analysis of the 'NIMBY' conflict, the local authorities' case.

be solved by providing information and educating the opponents, possible arguments in favor of the establishment of the infrastructure are externalities reduction and conservation of land, which leads to a higher standard of living.

\subsection{Strengths, Weaknesses, Opportunities, Threats - Results}

SWOT analysis was used to identify and analyze strengths, weaknesses, opportunities, and threats in the MSW market in Israel in terms of achieving the regulator's goal of decreasing landfilling via recycling and focus on strategic strengths and opportunities to advance the achievement of this goal and vision of IMoEP. Key persons were identified based on the survey conducted for mapping main actors in the MSW market by sectors as described in section 2.2.1.

The SWOT analysis for the Israeli market was carried out through an expert survey of 40 key persons from different sectors involved in the processes that were studied, either in the past or in the present. Table 1 shows the SWOT result for the Israeli MSW market.

\subsection{Core Competence Tree - Results}

The two core competencies that were identified are the high motivation of the government and known amount of MSW. Figure 3 illustrates the Core Competence Tree for the Israeli MSW market, derived from the desirable phenomena, resulted from tying logical connections between them.

\subsection{Focused Current Reality Tree - Results}

The four root problems that were identified are: (1) Lack of research (for the past 12 years IMoEP has not issued any call for proposal of research grants in the field of waste

TABLE 1: The SWOT results for the Israeli MSW market according to the experts' survey.

\begin{tabular}{|c|c|c|c|}
\hline Strengths & Weaknesses & Opportunities & Threats \\
\hline $\begin{array}{l}\text { 1. The regulator (The Ministry of } \\
\text { Environmental Protection) is com- } \\
\text { mitted to advanced MSW solutions. }\end{array}$ & $\begin{array}{l}\text { 1. Lack of cooperation between } \\
\text { the government and the local } \\
\text { authorities. }\end{array}$ & $\begin{array}{l}\text { 1. Advanced solutions such as } \\
\text { Waste to Energy are required. }\end{array}$ & 1. Risks due to regulatory instability. \\
\hline $\begin{array}{l}\text { 2. Local authorities are aware and } \\
\text { show interest in reducing MSW } \\
\text { landfilling. }\end{array}$ & $\begin{array}{l}\text { 2. Lack of research on operatio- } \\
\text { nal, environmental and economic } \\
\text { aspects. }\end{array}$ & $\begin{array}{l}\text { 2. Operation of advanced MSW tre- } \\
\text { atment facilities by local authorities } \\
\text { starting } 2014 \text {. }\end{array}$ & $\begin{array}{l}\text { 2. Very limited market for recyclable } \\
\text { materials. }\end{array}$ \\
\hline \multirow[t]{5}{*}{$\begin{array}{l}\text { 3. There are good statistical data on } \\
\text { the amount of waste produced. }\end{array}$} & $\begin{array}{l}\text { 3. Lack of measurement and } \\
\text { control. }\end{array}$ & & $\begin{array}{l}\text { 3. High volatility in the prices of } \\
\text { recyclable materials (e. g. plastic, } \\
\text { paper, and cardboard). }\end{array}$ \\
\hline & $\begin{array}{l}\text { 4. Lack of supervision and enfor- } \\
\text { cement. }\end{array}$ & & $\begin{array}{l}\text { 4. Inappropriate use and manage- } \\
\text { ment of the cleanliness fund. }\end{array}$ \\
\hline & 5. Lack of performance indicators. & & $\begin{array}{l}\text { 5. The "not in my back yard" (NIM- } \\
\text { BY) phenomena consist barriers } \\
\text { for the establishment of additional } \\
\text { advanced MSW treatment plants. }\end{array}$ \\
\hline & $\begin{array}{l}\text { 6. Regulatory instability (political } \\
\text { and official levels) }\end{array}$ & & $\begin{array}{l}\text { 6. There is no demand for compost } \\
\text { that's produced from MSW. }\end{array}$ \\
\hline & 7. Low quality of compost. & & \\
\hline
\end{tabular}


management). (2) Lack of cooperation between central government and local authorities. (3) Regulatory instability (four environmental protection ministers were replaced between the years 2014 to 2018) (4) Lack of measurement and control.

Figure 4 illustrates the Focused Current Reality Tree for the Israeli MSW market, derived from the undesirable phenomena, resulted from tying logical connections between them.

\subsection{Summary}

Regulation has a profound impact on markets. In order

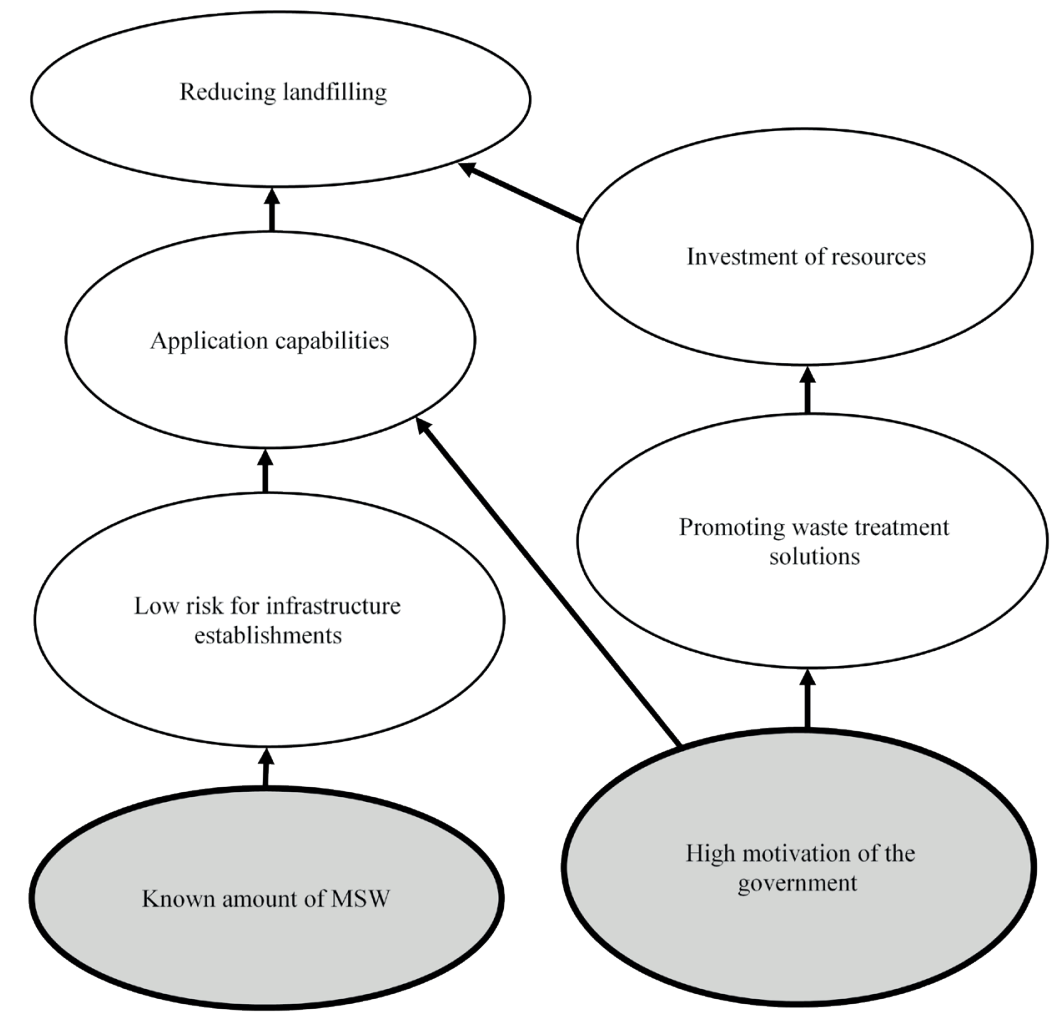

FIGURE 3: Core Competence Tree for identifying root competences in the Israeli MSW market.

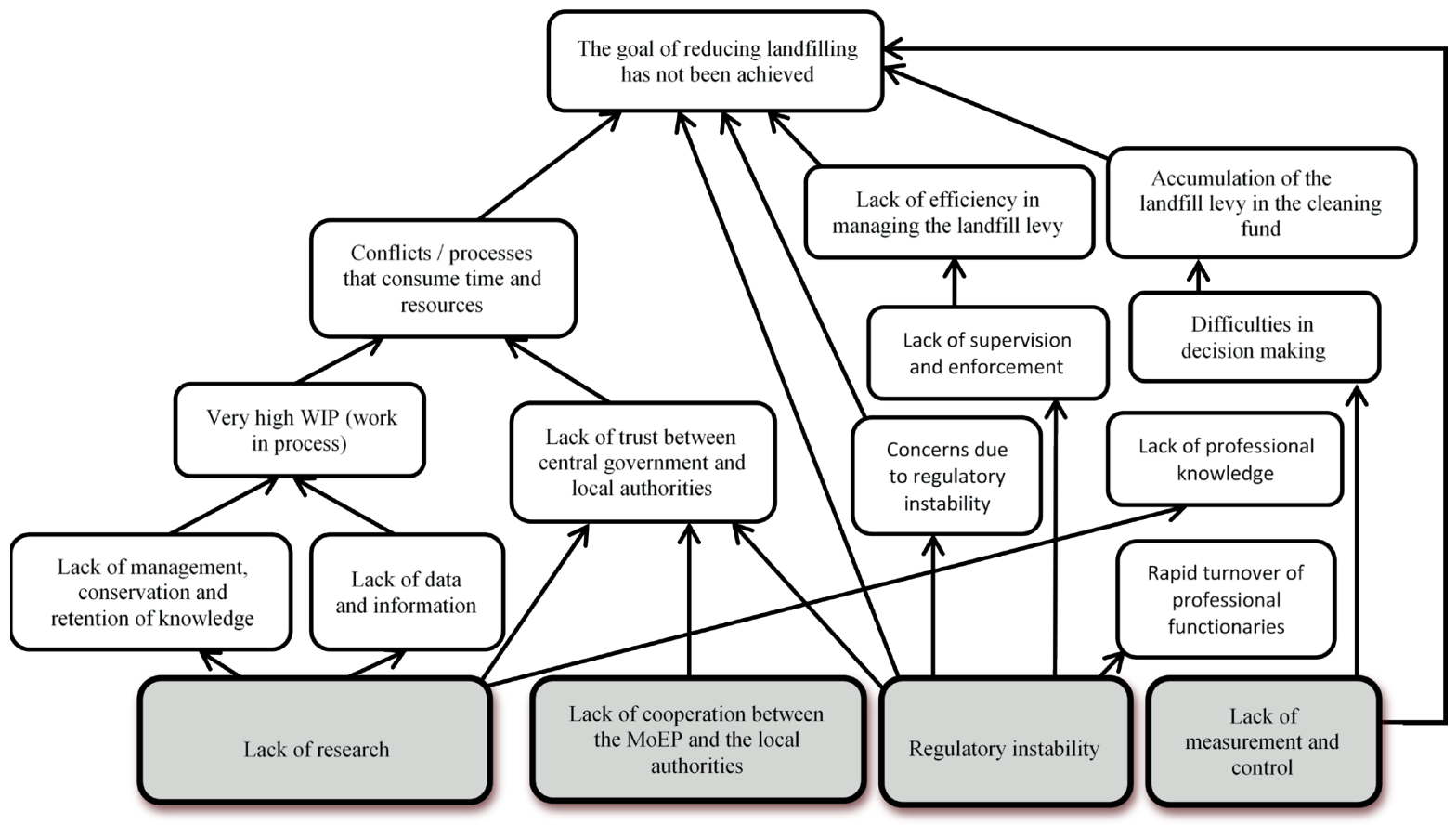

FIGURE 4: Focused Current Reality Tree for identifying root problems in the Israeli MSW market. 
to analyze the effects of regulation on the Israeli MSW market, an analysis of the market included the construction of the market's Arena, SWOT analysis and building of a Core Competence Tree and a Focused Current Reality Tree. The Arena was constructed in two stages: (1) Main actors were mapped according to different sectors. (2) Interrelationship and conflicts were identified.

The Arena analysis enabled identifying key persons for conducting a survey of experts for mapping phenomena in the market according to the four categories of SWOT. Core Competence Tree and Focused Current Reality Tree methodologies enabled analyzing the SWOT results and identifying 2 core competencies and 4 root problems aimed to advance the achievement of the goal defined by the IMoEP (the reduction of landfilling).

The results indicate a lack of cooperation and lack of coordination between the various sectors, particularly the central government and local authorities. The root problems that were identified are: (1) Lack of research. (2) Lack of cooperation between the IMoEP and the local authorities. (3) Regulatory instability. (4) Lack of measurement and control. The results highlight the crucial impact of regulation on the conduct of the Israeli MSW market, and the need for elaborating an ongoing RIA.

\section{CONCLUSIONS}

This paper presents a methodology for analyzing MSW markets. This methodology was implemented for analyzing the MSW market in Israel. The analysis tools presented include the construction of the market's Arena, SWOT analysis and building a Core Competence Tree (CCT) and a Focused Current Reality Tree (fCRT) for identifying core competencies and root problems. The results focusing on the Israeli MSW market, highlight the crucial impact of regulation on the conduct of the market and shows that regulation that was aimed for enhancing MSW management, induced barriers and undesirable effects that resulted in stagnation.

Limitations of this paper might stem from the limited number of participants in the expert survey, though it lays a good foundation for reflecting the state of the MSW market in Israel.

Being the residual end-of-life component of consumption products, MSW is a key factor in achieving a sustainable industry that lays the foundation for the circular economy. In the case of Israel, the analysis of the interrelationship between the Israeli MSW market and the regulation revealed root problems and core competencies that enabled taking a further step towards a forecast analysis for identifying better future regulation alternatives.

Market analysis is essential for understanding the impact of regulation on the market and its various stakeholders, such an insight is essential for the advancement of sustainable processes that will facilitate the achievement of a circular economy. The ensuing results indicate the importance of monitoring and assessing policy and regulations to examine whether regulation is, in fact, effective, what are the implications on the market and various stake- holders and what are the costs and benefits. Achievement of such insights requires the elaboration RIA continuously.

\section{REFERENCES}

Adelle, C., Weiland, S., Dick, J., González, O. D., Marquardt, J., Rots, G., Wübbeke, J., Zasada, I. (2014). Regulatory Impact Assessment - A Survey of selected and Emerging Economies, LIAISE discussion paper.

Agamuthu, P., (2013). Landfilling in developing countries. Waste Management \& Research 31: 1-2.

Arndt, C., Custance, A., Baker, T. Q., \& Schultz, R. (2015). 2015 Indicators of Regulatory Policy and Governance. Available at: http:// www.oecd.org/governance/regulatory-policy/WP1_Design-Methodology-Key-Results.pdf (accessed 17.11.18).

Ayalon, O., Avnimelech, Y., \& Shechter, M. (1999). Issues in designing an effective solid waste policy: the Israeli experience. The market and the environment: The effectiveness of market based instruments for environmental reform. Edward Elgar, UK, 389-406.

Ayalon, O., Avnimelech, Y., \& Shechter, M. (2000). Alternative MSW treatment options to reduce global greenhouse gases emissionsthe Israeli example. Waste Management and Research, 18(6), 538544.

Broitman ,D., Ayalon, O., Kan, I. (2012). One size fits all? An assessment tool for solid waste management at local and national levels, Waste Management 32: 1979-1988.

Central Bureau of Statistics (2017). Population \& Demography. [In Hebrew.] Available at: http://www.cbs.gov.il/reader/?Mlval=cw_usr_ view_SHTML\&ID=705 (accessed 17.11.18).

Coman, A. (2008). ARENA Mapping: An effective strategy focusing tool, Human System Management 27(4): 305-312.

Coman, A., \& Ronen, B. (2002). Focused-arena-strategy-fast: Transforming Strategic Core-competences and Root-problems Into Action. Israel Institute of Business Research.

Coman, A., Ronen, B. (2009). Focused SWOT: diagnosing critical strengths and weaknesses, International Journal of Production Research 47(20): 5677-5689.

Daskal, S., Ayalon, O., \& Shechter, M. (2018). The state of municipal solid waste management in Israel. Waste Management \& Research, 0734242X18770248.『

Di Maria, F., Mersky, R.L., Daskal, S., Ayalon, O., Ghosh, S.K. (2017) Preliminary comparison among recycling rates for developed and developing countries: The case of India, Israel, Italy and USA. In: Proceedings of 7th IconSWM, Hyderabad, India, 15-17 December.

EC-European Commission. (2016). Circular Economy Strategy: Closing the loop-An EU action plan for the Circular Economy. Available at: http://eur-lex.europa.eu/legal-content/EN/TXT/?uri=CELEX:52015DC0614 (accessed 17.11.18).

Eshet, T., Baron, M., Ayalon, O., Shechter, M. (2007). Measuring externalities of waste transfer stations in Israel using hedonic pricing, Waste Management 27: 614-625.

Garber, A. M., \& Phelps, C. E. (1997). Economic foundations of cost-effectiveness analysis, Journal of Health Economics 16: 1-31

Garrar, M. B. (1993). The Victims of NIMBY, Fordham Urban Law Journal 21(3): 494-522.

Goldratt, E. M., \& Cox, J. (2016). The goal: a process of ongoing improvement. Routledge.

Graczyk, M., \& M. Rybaczewska-Błażejowska, (2007). ISO 14001 and sustainable development of the municipal waste sector in Poland: SWOT analysis, Management 11(1): 161-166.

Halstead, J. M., Luloff, A. E., Mayers, S. D. (1993). An Examination of The NIMBY Syndrome: Why Not In My Backyard, Community Development Society 24: 88-102.

Horst, V. D. D. (2007). NIMBY or not? Exploring the relevance of location and the politics of voiced opinions in renewable energy siting controversies, Energy Policy 35: 2705-2714.

IMoEP (2018). Solid Waste. Available at: http://www.sviva.gov.il/ English/env_topics/Solid_Waste/Pages/default.aspx (accessed 17.11.18).

Johannesson, M. (1995). The relationship between cost-effectiveness analysis and cost-benefit analysis, Social science \& medicine 41(4): 483-489

Kinnaman, K. (2014). Understanding the Economics of Waste: Drivers, Policies, and External Costs, International Review of Environmental and Resource Economics 8: 281-320. 
Kirkpatrick, C. H., \& Parker, D. (Eds.). (2007). Regulatory impact assessment: towards better regulation?. Edward Elgar Publishing.

Kirkpatrick, C., Parker, D., \& Zhang, Y. F. (2004). Regulatory impact assessment in developing and transition economies: a survey of current practice. Public money and management, 24(5), 291-296.

Lee, F. G., Jones, R. A. (1991). Municipal Solid Waste Management Long-Term Public Health and Environmental Protection, Prepared for Workshop Landfills and Groundwater Quality, NWWA National Outdoor Action Conference, Las Vegas, Nevada. Available at: http://www.gfredlee.com/Landfills/MSWMANAGT.pdf (accessed 17.11.18)

Marques, R. C., \& Simões, P. (2008). Does the sunshine regulatory approach work?: Governance and regulation model of the urban waste services in Portugal. Resources, Conservation and Recycling, 52(8-9), 1040-1049 (accessed 17.11.18).

Mor, S., Kaur, K., Khaiwal, R. (2015). SWOT analysis of waste management practices in Chandigarh, India and prospects for sustainable cities, Journal of Environmental Biology, 37: 327-332

Nakazawa, T. (2015). Politics of distributive justice in the siting of waste disposal facilities: the case of Tokyo, Environmental Politics: 1-22.

Nissim, I., Shohat, T., Inbar, Y. (2005). From dumping to sanitary landfills - solid waste management in Israel, Waste Management 25: 323-327.

OECD (2002). Regulatory policies in OECD countries: from interventionism to regulatory governance. Paris: OECD. Available at: http:// www.oecd-ilibrary.org/governance/regulatory-policies-in-oecdcountries_9789264177437-en (accessed 17.11.18).

OECD (2006). Cost-Benefit analysis and the environment: recent developments, ISBN 92-64-01004-1

OECD (2009). Regulatory Impact Analysis, a tool for policy coherence. Available at: https://read.oecd-ilibrary.org/governance/regulatory-impact-analysis_9789264067110-en\#page1 (accessed 17.11.18).

OECD (2011). Regulatory Management Indicators, ISRAEL. Available at: https://www.oecd.org/gov/regulatory-policy/47827319.pdf (accessed 17.11.18)

OECD (2015). 2014 Regulatory Indicators Survey results, Measuring Regulatory Performance. Available at: http://www.oecd.org/gov/ regulatory-policy/ria.htm(accessed 17.11.18).

Pan, S. Y., Du, M. A., Huang, I. T., Liu, I. H., Chang, E. E., \& Chiang, P. C (2015). Strategies on implementation of waste-to-energy (WTE) supply chain for circular economy system: a review. Journal of Cleaner Production, 108, 409-421.
Pesonen, H. L., \& Horn, S. (2013). Evaluating the Sustainability SWOT as a streamlined tool for life cycle sustainability assessment. The International Journal of Life Cycle Assessment, 18(9), 17801792.

Rachid, G., Fadel, M. (2013). Comparative SWOT analysis of strategic environmental assessment systems in the Middle East and North Africa region, Journal of Environmental Management 125: 85-93

Radaelli, C. M., \& De Francesco, F. (2007). Regulatory impact assessment, political control and the regulatory state. In 4th general conference of the European consortium for political research (Vol. 4).

Rahardyana, B., Matsutoa, T., Kakutab, Y., Tanakaa, N. (2004). Resident's concerns and attitudes towards Solid Waste Management Facilities, Waste Management 24(5): 437-451.

Ronen, B. (Ed.). (2005). The theory of constraints: practice and research. IOS Press.

Ronen, B., \& Pass, S. (2008). Focused operations management: Achieving more with existing resources. John Wiley \& Sons.

Rosen-Zvi, I. (2007). Whose Garbage is it Anyway?! Garbage Disposal and Environmental Justice in Israel. Bar-Ilan Law Studies (2): 487558.

Schneider, D. R., Kirac, M., Hublin, A. (2012). Cost-effectiveness of GHG emission reduction measures and energy recovery from municipal waste in Croatia, Energy 48: 203-211

Simões, P., \& Marques, R. C. (2012a). On the economic performance of the waste sector. A literature review. Journal of environmental management, 106, 40-47.

Simões, P., \& Marques, R. C. (2012b). Influence of regulation on the productivity of waste utilities. What can we learn with the Portuguese experience?. Waste management, 32(6), 1266-1275.

Srivastava, P. K., Kulshreshtha, K., Mohanty, C. S., Pushpangadan, P. Singh, A. (2005). Stakeholder-based SWOT analysis for successful municipal solid waste management in Lucknow, India, Waste Management 25: 531-537

Sterner, T., Coria, J. (2012). Policy Instruments for Environmental and Natural Resource Management. Resources for the Future.

Yuan, H. (2013). A SWOT analysis of successful construction waste management, Journal of Cleaner Production 39: 1-8.

Zurbrugg, C., Caniato, M., Vaccari, M. (2014). How Assessment Methods Can Support Solid Waste Management in Developing Countries - A Critical Review, Sustainability 6: 545-570. 